A. Sładkowski ${ }^{1}$, Dr. Sc. (Tech.), Prof., orcid.org/0000-0002-1041-4309,

A.Utegenova ${ }^{2}$, orcid.org/0000-0001-9098-6325,

S. Kuzmin 3 , Cand. Sc. (Tech.), orcid.org/0000-0003-1934-9408,

B. Rakishev ${ }^{2}$, Acad. of the National Academy of Sciences

of the Republic of Kazakhstan, Dr. Sc. (Tech.), Prof., orcid.org/0000-0001-5445-070X,

I. Stolpovskikh², Dr. Sc. (Tech.), Prof., orcid.org/0000-0003-2893-5070
1 - Silesian University of Technology, Katowice, Poland, e-mail: aleksander.sladkowski@polsl.pl

2 - Satbayev University, Almaty, the Republic of Kazakhstan, e-mail: asem u 18@mail.ru

3 - Ore Industrial Institute, Rudny, the Republic of Kazakhstan, e-mail: decan_2008@mail.ru

\title{
ENERGY ADVANTAGES OF CONTAINER TRANSPORT TECHNOLOGY IN DEEP CAREERS
}

Purpose. To substantiate the rational parameters of a new container technology for moving rocks in quarries which has technological and energy-saving advantages.

Methodology. The work used a set of scientific research methods: scientific synthesis; technical and economic analysis of operating experience of transport systems; energy analysis of open pit mining processes; economic-mathematical and multivariate analysis.

Findings. As a result of the completed design and technical and economic calculations, the rational parameters of the new container technology for moving the rock mass in the quarries were substantiated.

Originality. For the first time, a comprehensive analysis of the operation of transport systems in open pits was carried out based on an analysis of the structure and dynamics of energy consumption in deep pits. It was established that energy consumption for technological transportation in deep quarries ranges from 22-55\% for assembly transportation and to $85-90 \%$ for trunk transportation in total energy consumption for mining rock mass. To improve the energy efficiency of transport systems of quarries, rational constructive and regime parameters of the new container technology in deep quarries are justified, which allows changing the principles of formation of excavators and transport complexes, increasing their productivity and energy efficiency. A method has been developed for calculating technical, economic and energy indicators of container technology for transporting rock mass, based on geoinformation modeling of the mining front and production facilities of deep pits.

Practical value. Based on the established rational parameters of the new container technology, at the design stage, it is possible to make reasonable technical decisions that ensure the energy efficient operation of deep-pit transport systems.

Keywords: container technology, deep quarry, lifting machine, container, productivity, open pit mining, excavator transport complex

Introduction. Completion of technological equipment for deep quarries is the most difficult issue in the technology of existing quarries. This shows that they contain a number of contradictions that require new solutions.

Currently, there are two main technologies used to transport rock from deep quarries. This is transportation with the help of heavy-duty dump trucks and conveyor transportation. The efficiency of career rail transport with very large slopes is low. It is also possible to use combined technologies that involve the use of several transport modes.

The main goal of this article is to analyze the energy efficiency of promising, relatively new technologies for transporting rock mass.

Literature review. Let us consider first the case of road transport. As mining operations decrease in open-pit mines, the distance of road transport increases, and therefore larger dump trucks are required. Increasing the loading capacity of dump trucks violates the optimal ratio of the capacity of the bottomhole excavator bucket to the capacity of the body of the dump truck. To reduce downtime for expensive dump trucks, you need to increase the bucket capacity and the standard size of the excavator. The increased size of dump trucks requires the expansion of roads, maneuvering sites, etc., which significantly reduces the volume of mined rock. This contributes to an increase in the number of intra-career transshipment points used in combined transport. The optimal location of such points is a very important task of planning the extraction and further transportation of the rock mass [1].

(c) Sładkowski A., Utegenova A., Kuzmin S., Rakishev B., Stolpovskikh I., 2019
The efficiency of the use of road transport for the rock mass transportation from deep quarries was previously considered by the authors in paper [2]. However, the use of combined transport seems to be more efficient.

In deep quarries with a combined road-rail transport with an increase in the depth of the quarry, the pace of construction of railway utilities and cargo warehouses gradually decreases due to the narrowing of the working space. The lag from advanced overburden works is slowing down in order to form areas of a permanent pit wall. Such sites require stationary rail links to be placed on them. The lag of overburden operations in the area of operation of railway transport is due to the lower possible intensity of mining operations caused by a large length of the working front for one excavator on railway transport.

Different rates of decline in mining operations in road and rail transport also contribute to the emergence of an increasing separation of the car boundaries of the lower zone of the open pit from the transshipment warehouses located at the lower boundary of the zone of operation of the rail transport.

The result of the above situation is a qualitative transition of vehicles from the category of link, which has the main advantage in mobility, in the category of lifting link of the transport system, under conditions at which the worst properties of vehicles are reduced - high specific fuel consumption and extremely negative impact on the open pit atmosphere [3]. According to practical data, the specific consumption of a dump truck on the rise doubles, which is associated with a high capacity coefficient and low efficiency of any internal combustion engine [4]. The specific cost of mining increases, the frequency of pit stops for airing increases, or the need arises to 
use personal protective equipment against harmful gases [5]. Some technical solutions allow improving the process of transportation of rock mass [6].

The main disadvantages inherent in traditional technologies with road, rail and combined road and rail transport are the following [7]: high tare coefficient of the body of motor vehicles; small gradients of transport communications in a career; decrease in the productivity of excavators, automotiveexcavator and railway complexes due to insufficient supply of excavators with the necessary number of vehicles to reduce the downtime of expensive equipment; the need for additional energy-intensive excavations in case of overloading of the rock mass in the intra-opencast warehouses with combined transport; high level of formation of dust when overloading the rock mass in warehouses, during transportation and storage; increased height of rock lifting in external dumps and the need for additional equipment for dumping (bulldozers, excavators) of the rock mass; an increase in the current stripping ratio due to the deviation from the optimal direction of the formation of the intermediate pit wall when placing transport communications and transshipment warehouses on temporary supports in the working area of the quarry; the inability to automate the process of transporting the lifting of the rock mass from the pit.

If we analyze the conveyor method of transportation, then its main disadvantages are: difficulties of blasting in the area where the conveyor lines are located; the need for energy-intensive crushing of waste rock before loading on the conveyor; downtime of mining equipment during reorganizations, maintenance and repair of conveyor lines and crushing equipment; an increase in the current stripping ratio due to a deviation from the optimal direction of the rate of decrease when placing crushing plants and conveyor lines at the lower balance in the working area of the quarry; intense dust generation during the grinding of the rock in the quarry and its reloading from the dump trucks to the crushing plant bunker; the need to organize the heating of the conveyor to work in winter [8].

The use of cyclic-and-continuous technology in quarries makes it possible to partially improve the combined method of transportation [9]. The key issue when using this technology is to determine the location of transfer points $[10,11]$.

There are also technologies for which the use of special lifts for quarries (for dump trucks, railway cars, skips) is proposed. The main disadvantage of these technologies is the need to build on-board quarry of a stationary route of guides and lifting mechanisms. The inflexibility of this transportation scheme, in the conditions of a dynamically developing working area of the open pit with blasting operations, limits the zone served by the hoist or has an adverse effect on the mode of mining when the hoist is placed in the working zone of the quarry [12].

Thus, the main problem of deep quarries is the transport problem. Modern trends in the development of traditional transportation technologies lead to a reduction in reserves of fossil ores, an increase in unit costs per 1 ton-km of road transport, an increase in atmospheric pollution and a decrease in production capacity of the open-pit.

The main material. For the introduction of open-pit mining, a container technology for transporting rock mass is proposed, which will increase the open-pit mining of energy saving and environmental preservation at a qualitatively new level.

The main feature of the proposed technology is that all equipment for container transport is not difficult to manufacture and can be produced at mining enterprises. Obsolete walking mining excavators can be used as lifting machines.

In accordance with the basic technological scheme of the quarry, lifting containers are installed on the ledges of the quarry to raise the containers from the lower ledges upwards

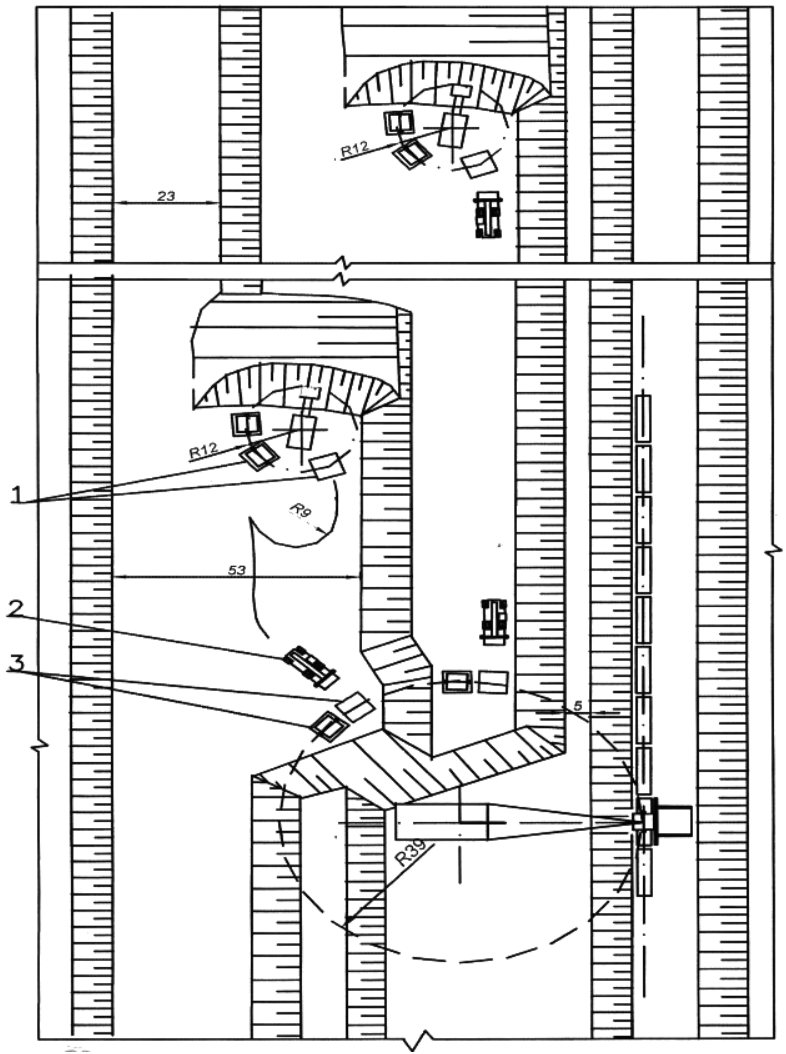

Fig. 1. Scheme of energy-saving container technology in open pit mining:

1 - containers under loading; 2 - container vehicles; 3 - containers at the site at the lifting machine

(according to Fig. 1). On intermediate platforms, loaded and empty containers are cleaned. After climbing to the ledges, where the railway transport operates, the container is unloaded directly into the wagons.

One lifting machine serves two benches when lifting. The lifting machine is located on the platform of the lower ledge outside the prism of a possible collapse.

The container is delivered by the container ship to the lower edge of the lower ledge, the lifting machine moves the container to the upper ledge platform, from where the container is fed to the next lifting machine through the exchange point.

The new technology can be used in existing combined transport schemes, for example, automobile-rail, as an intermediate - lifting and handling point.

Container lifting complex can be an alternative solution to the acute problem of modern quarries to open deep horizons, although it can be applied at any stage of the development of the quarry.

The refusal to lift the mountain mass by motor transport makes it possible to increase the maximum slopes of the descent, since they will be used for driving only empty cars. A possible transition from $8 \%$ slopes to $15 \%$ slopes will result in a reduction in the area allotted in a quarry to accommodate an auto descent.

In the container technology, rock mass according to Fig. 1 is loaded with excavators in containers. Two or three containers are installed in the area of the excavator. The exchange of loaded containers for empty ones is carried out by autoloaders - container carriers. They deliver loaded containers for short distances to the container platform in the working area of the next lifting device. Container vehicles also carry empty containers into the quarry.

Based on the analysis of existing containers that are used in the industry for the transportation of goods, it was found 
that none of the container designs suits us. Basically, containers are used to transport loose fine goods, and for the transportation of lumpy abrasive rock, the patent search conducted has not given positive results. For transportation of rocks in a deep quarry, a container was designed that has no analogues (Fig. 2). The design of the container is protected by the patent of the Republic of Kazakhstan No. 33091 [13, 14].

Structurally, the container is welded, with a drop-down bottom. The opening of the bottom is controlled by the operator of the lifting machine due to the system of mechanical levers. All container assembly elements are tested for mechanical strength using computer simulation methods.

The bottom section is attached to the walls on five hinges. When loading, the container is installed on the ground, and the bottom sections are fixed with a locking element - a knee. The container is lifted by the side fittings located on the side walls. In this case, the stops of the load gripping device come into contact with the fittings and keep the container in the closed state. During the unloading process, the stops are released from contact with the fittings, and due to their own weight, the rock is poured out of the container. The bottom closure occurs when the container is installed on the stand, which causes the bottom sections to move upwards until they are completely in contact with the knee.

The bottom of the container is one of the most loaded parts and directly perceives the load of the weight of the transported rock, as well as the dynamic load from lifting, transporting and lowering to the surface. In addition, this part of the container perceives the main load from the impact of the loaded rock mass. For the manufacture of the bottom of the container, steel St60 (possible US analogues 1059, 1060, 1064, C1060, G10590, G10600, G10640) is used.

The most labor-intensive operations in the production of loading and unloading operations with large cargoes are their slinging and detaching. Performing these operations manually requires large expenditures of inefficient and unsafe labor of loaders and prevents the introduction of complex mechanized and automated technological processes for loading and unloading. In our case, the usual lifting device is not suitable and, therefore, it is advisable to use a spreader.

The following requirements are imposed on the designed spreader: high reliability coefficient and reliability, economical operation, which allows increasing the service life and largely avoiding container deformation, automating container pickup, the possibility of unloading the container and the simplicity of the design. Known constructions of spreaders do not meet the requirements of open pit mining; therefore, the de- sign of the spreader was developed to lift containers in a quarry (in accordance with Fig. 3).

When transporting containers, the pickup device consists of a supporting beam 1 , which is equipped with rectangular grippers 2 . The length of the beam increases, and both sides are extended with the help of hydraulic cylinders 3. The grippers move to clamp the container. The beam is equipped with hydraulic cylinders 4 , providing unloading of the container. The control hydraulic station 5 is located on the support beam and includes: engine, pumps and control valves. A gear that is rotated by a hydraulic motor located on the spreader 6 is used to center the container. The beam of the traverse is made of steel grade 10HSND. The material of the bracket for unloading on the container is steel St10 (US analogues 1010, 1012, 1110, C1010, Gr.A, M1010, M1012).

The calculation of the hydraulic system of the unloading device was carried out. The hydraulic drive uses standard assembly items and parts. Hydraulic oil VMGZ (TU 101479-74) is used as a working fluid. The container with the spreader is shown in Fig. 4.

The efficiency of the new technology will be reflected in the reduction of the specific energy consumption for transportation of the rock mass compared to the most common technology using road and rail transport with overloading into intra-warehouse warehouses due to cost savings: to lift the rock mass due to lifting it with electric powered hoppers in containers having minimum tare coefficient; from reducing the overburden by reducing the area of the transshipment point, the device of which in this case loses its significance.

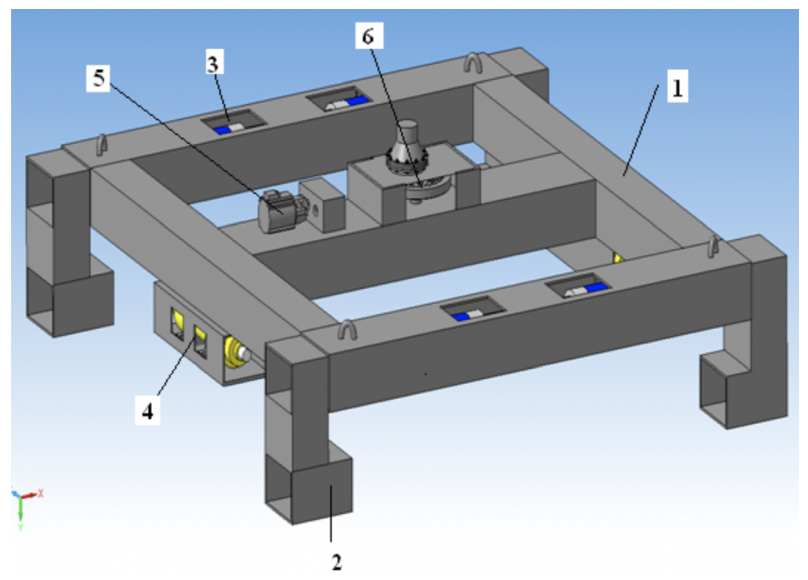

Fig. 3. General view of the gripping device

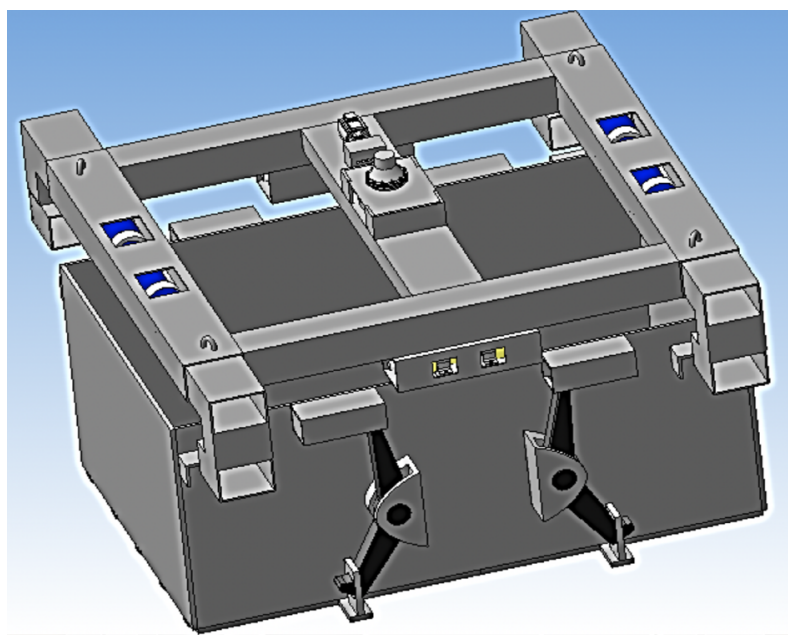

Fig. 2. General view of the container

Fig. 4. View of the container with the spreader

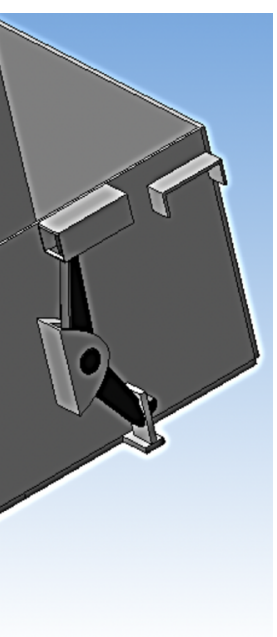

2, Naukovyi Visnyk Natsionalnoho Hirnychoho Universytetu, 2019, № 5 
The lifting capacity of the lifting machine is justified by the required productivity of the quarry. The capacity of the lifting machine $Q_{y}$, thousand tons/year, will be determined depending on the time of its operating cycle $T_{c}$ according to the textbook formula

$$
Q_{y}=3600 \cdot T_{a f} \cdot K_{e u} \cdot G_{c} \cdot K_{u} / T_{c},
$$

where $T_{a f}=8760$ is calendar annual fund of time, $\mathrm{h} ; K_{e u}=0.75$ is the coefficient of equipment use; $G_{c}$ is container carrying capacity, $\mathrm{t} ; K_{u r}=0.95$ is capacity utilization rate; $T_{c}$ is cycle time, s.

Let us estimate the impact on the productivity of the container capacity complex, and the cycle time is taken on the basis of the lifting speed of the walking excavator, $1 \mathrm{~m} / \mathrm{s}$. The lifting time to a height of 80 meters will be 80 seconds, taking into account the takeover, the total cycle time of the lifting machine $T_{c}=220$ seconds.

When moving a dump truck, the rise time to a height of $H=80$ meters with a slope of $i=80 \%$ and an average speed of $V=15 \mathrm{~km} / \mathrm{h}$ will be $(\mathrm{h})$

$$
t=H /(1000 \cdot i \cdot V)=80 /(1000 \cdot 0.08 \cdot 15)=0.067 \text {. }
$$

Therefore, when driving a dump truck, only the lifting time of the car will be 240 seconds.

The effect of container carrying capacity $\left(G_{c}\right)$ on the productivity of lifting devices $\left(Q_{y}\right)$, defined by formula (1), is shown in Fig. 5.

Analyzing this graph, it can be noted that one complex of lifting devices with containers with a lifting capacity of 80 tons can provide a capacity of about 9 million tons/year, and if more capacity is required, it is necessary to increase the number of lifting systems.

Results. The efficiency of container lifting in container technology of open pit mining is to reduce energy and economic losses from vehicle downtime under loading and to increase excavator productivity. The container vehicle cycle does not include downtime during loading, unlike dump trucks and railway trains.

Technological scheme with the use of career elevators has sufficient reliability, flexibility and diversity. This allows you to gradually increase the height of the lift, to place the complex of lifting equipment on the ledges of the quarry, to distribute or combine the flow of goods according to the types of rock mass.

In this case, a means of improving the efficiency of the transport system will be the use of container equipment in the area of operation of motor vehicles, based on increasing the carrying capacity of container vehicles with the help of traction motors with electric drive. With an insufficient lift height with one lifting mechanism, two- or three-stage lifting is pos-

Quarries productivity [mln. tons/year]

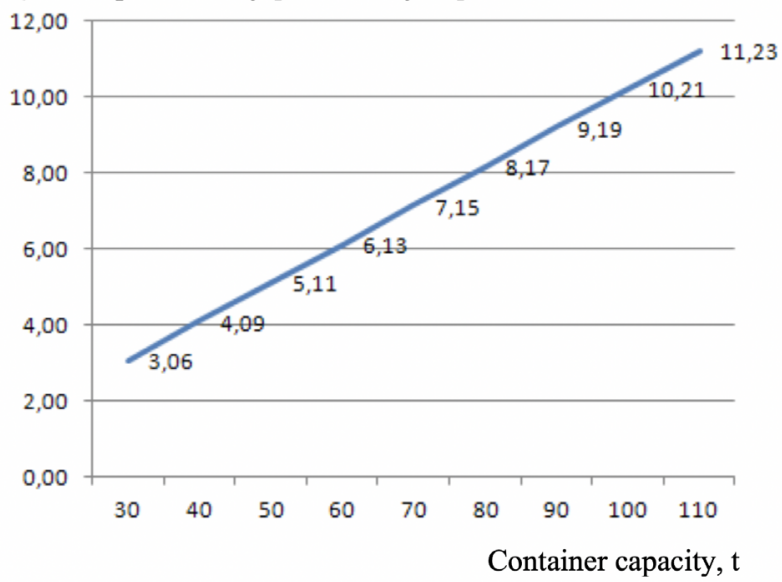

Fig. 5. The effect of container carrying capacity on the productivity of the lifting complex sible. This will reduce or eliminate the lifting of containers by container carriers that deliver loaded containers from excavators to lifting points.

The advantages of the proposed technology are as follows:

1. One-time rock loosening during container loading which reduces energy consumption.

2. Delivery of the rock mass by transporting the container assembly to the point of lifting is carried out at the minimum horizontal distances of the road, which leads to a decrease in the required vehicle fleet, specific fuel consumption, tires and emission of harmful gases into the atmosphere.

3. The tare factor of the transport container $(0.25-0.30)$ is significantly less than the ratio of the automobile body $(0.70-0.80)$ or railway transport $(0.80-0.82)$, therefore the unit cost of energy for moving the mass of mountain rocks in container lift is reduced 1.4 times [12].

4. The complex of container-lifting machines is mobile, which allows you to move to a new place in the production of blasting or another ledge in a career with consistent development of quarries. The possibilities of regulating and maintaining the regime of optimal mining are increasing.

5. The need for additional energy-intensive grinding of the rock mass is eliminated in contrast to the technological schemes using conveyor elevators.

6. Container delivery of overburden when using a pit lift during pit removal will reduce the required land area and form a compact height with minimal lifting of the rock.

Calculations of the use of container technologies in deep quarries showed that in comparison with traditional options for moving the mountain mass of an automobile or a combined automobile-rail, the energy efficiency of the new technology is obvious and its degree increases with increasing height of the mountain mass.

The number of equipment units for the two technologies with the use of road and container transport at different pit depths and productivity of 10.2 million tons per year is given in Table 1. When used in an open-pit mine as an excavator, ECG$8 \mathrm{Uc}$ was considered as an excavator, which leads to loading onto Cat-777D dump trucks.

The number of downhole excavators for automotive technology will be -2 , and for container technology -1 . Container transport to the transfer point is carried out by three container vehicles. With every 80 meters, the number of lifting machines increases by one. With automotive technology, a reloading warehouse is needed, where another excavator will work.

Table 1

Working equipment park at different pit depths

\begin{tabular}{|l|c|c|c|c|c|c|c|c|}
\hline \multirow{2}{*}{$\begin{array}{c}\text { Equipment name, } \\
\text { amount }\end{array}$} & \multicolumn{7}{|c|}{ Career depth, m } \\
\cline { 2 - 10 } & 40 & 80 & 120 & 160 & 200 & 240 & 280 & 320 \\
\hline \multicolumn{7}{|c|}{ Technology using road transport } \\
\hline Excavators & 3 & 3 & 3 & 3 & 3 & 3 & 3 & 3 \\
\hline Dump trucks & 4 & 6 & 8 & 10 & 10 & 12 & 14 & 16 \\
\hline \multicolumn{7}{|c|}{ Container technology } \\
\hline Excavators & 1 & 1 & 1 & 1 & 1 & 1 & 1 & 1 \\
\hline Lifting machines & 1 & 1 & 2 & 2 & 3 & 3 & 4 & 4 \\
\hline Containers & 6 & 7 & 12 & 13 & 16 & 17 & 21 & 22 \\
\hline Railway carts & 0 & 0 & 2 & 2 & 4 & 4 & 6 & 6 \\
\hline Winches & 0 & 0 & 2 & 2 & 4 & 4 & 6 & 6 \\
\hline Container vehicles & 3 & 3 & 3 & 3 & 3 & 3 & 3 & 3 \\
\hline $\begin{array}{l}\text { Length of the railway } \\
\text { track, m }\end{array}$ & 0 & 0 & 200 & 200 & 400 & 400 & 600 & 600 \\
\hline
\end{tabular}


Calculation of necessary expenses

\begin{tabular}{|c|c|c|c|c|c|}
\hline 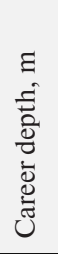 & 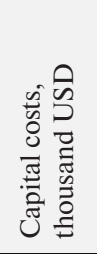 & 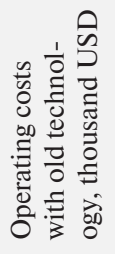 & 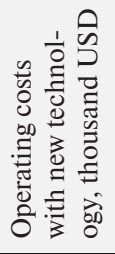 & 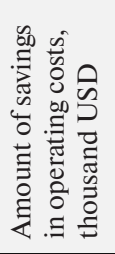 & 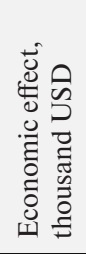 \\
\hline 40 & 2450.8 & 4813.6 & 3271.5 & -1542.1 & 1149.8 \\
\hline 80 & 2450.8 & 6122.3 & 3289.8 & -2832.5 & 2440.2 \\
\hline 120 & 2769.0 & 7426.0 & 4165.0 & -3260.7 & 2817.6 \\
\hline 160 & 2769.0 & 8682.0 & 4183.3 & -4498.8 & 4055.9 \\
\hline 200 & 3087.3 & 9632.8 & 5022.3 & -4610.5 & 4139.8 \\
\hline 240 & 3087.3 & 9933.4 & 5040.6 & -4892.9 & 4399.1 \\
\hline 280 & 3405.3 & 11230.0 & 5897.8 & -5332.2 & 4787.5 \\
\hline 320 & 3405.3 & 12517.0 & 5915.8 & -6601.2 & 6056.5 \\
\hline
\end{tabular}

Economic effect, thousand USD

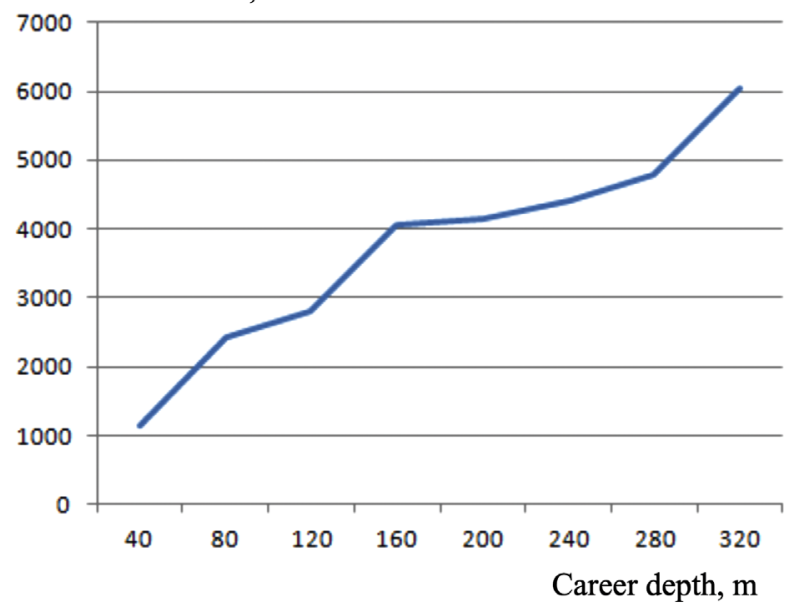

Fig. 6. The dependence of the economic efficiency of the introduction of container technology on the depth of the pit

Calculation of the necessary costs with a capacity of 10.2 million tons per year, depending on the depth of the pit, is presented in Table 2.

Diagram of the growth of economic efficiency of container technology, depending on the depth of the pit is presented in Fig. 6. Analyzing this graph, we can conclude that the economic efficiency of the introduction of container lifting at a quarry increases with increasing depth of development. This is due to the reduction of operating costs, such as the consumption of diesel fuel, depreciation and reduction of the cost of repairs of equipment.

Conclusions. Container technology in its application in deep quarries allows solving the whole complex of problems of the basic technological processes of open-cast mining. The use of replaceable containers in open pits will significantly change the principles of the formation of excavators and transport complexes, will increase their productivity and efficiency of excavators on the main work.

Replacing outdated mining vehicles with progressive equipment will provide increased transport safety, increase the degree of utilization of the mining front and production capacity of the quarries. The most important advantage of container technologies is the prospect of automating a number of transport operations in a quarry. All equipment container technology can be created by the mining enterprise itself.
Recommendations. Reasonable design mode parameters, method of calculation of technical, economic and energy indicators of container technology in deep quarries can be recommended to research organizations and industrial enterprises engaged in research, design and operation of excavator-automotive complexes in open-pit mining.

\section{References.}

1. Oggeri, C., Fenoglio, T. M., Godio, A., \& Vinai, R. (2019). Overburden management in open pits: options and limits in large limestone quarries. International Journal of Mining Science and Technology, 29(2), 217-228. DOI: 10.1016/j. ijmst.2018.06.011.

2. Mahambetov, D., Rakishev, B., Samenov, G., \& Sładkowski, A. (2013). Efficient using of automobile transport for the deep open-pit mines. Transport Problems, 8(3), 25-32.

3. Yakovlev, V. L., Bahturin, Yu. A., \& Zhuravlev, A. G. (2015). Main aspects of forming and new scientific directions of research of open pit mining transport systems. Science and Education, (4), 67-72.

4. Taran, I., \& Bondarenko, A. (2017). Conceptual approach to select parameters of hydrostatic and mechanical transmissions for wheel tractors designed for agrucultural opeations. Archives of transport, 41(1), 89-100. DOI: 10.5604/01.3001.0009.7389.

5. Braun, T., Hennig, A., \& Lottermoser, B. G. (2017). The need for sustainable technology diffusion in mining: Achieving the use of belt conveyor systems in the German hard-rock quarrying industry. Journal of Sustainable Mining, 16(1), 2430. DOI: 10.1016/j.jsm.2017.06.003.

6. Sładkowski, A., Utegenova, A., Kolga, A.D., Gavrishev, S. E., Stolpovskikh, I., \& Taran, I. (2019). Improving the efficiency of using dump trucks under conditions of career at open mining works. Naukovyi Visnyk Natsionalnoho Hirnychoho Universytetu, 2, 113-122. DOI: 10.29202/nvn$\mathrm{gu} / 2019-2 / 8$.

7. Koryagin, M., \& Voronov, A. (2017). Improving the organization of the shovel-Truck systems in open-pit coal mines. Transport Problems, 12(2), 113-122. DOI: 10.20858/ tp.2017.12.2.11.

8. de Almeida, C.M., de Castro Neves, T., Arroyo, C., \& Campos, P. (2019). Truck-and-loader versus conveyer belt system: an environmental and economic comparison. WidzykCapehart E. et al. (eds.) Proceedings of the 27th International Symposium on Mine Planning and Equipment Selection - MPES 2018 (pp. 307-318). Springer Nature Switzerland AG. DOI: 10.1007/978-3-319-99220-4 25.

9. Sładkowski, A., Utegenova, A., Elemesov, K., \& Stolpovskikh, I. (2017). Determining of the rational capacity of a bunker for cyclic-and-continuous technology in quarries. Naukovyi Visnyk Natsionalnoho Hirnychoho Universytetu, 6, 29-33.

10. Roumpos, C., Partsinevelos, P., Agioutantis, Z., Makantasis, K., \& Vlachou, A. (2014). The optimal location of the distribution point of the belt conveyor system in continuous surface mining operations. Simulation Modeling Practice and Theory, 47, 19-27. DOI: 10.1016/j.simpat.2014.04.006.

11. Rahmanpour, M., Osanloo, M., Adibee, N., \& AkbarpourShirazi, M. (2014). An approach to determine the location of an in-pit crusher in open pit mines. International Journal of Engineering (IJE) Transactions C, 27(9), 1475-1484. DOI: 10.5829/idosi.ije.2014.27.09c.18.

12. Health and Safety at Opencast Mines, Alluvial Mines and Quarries (2015). Retrieved from https://worksafe.govt.nz/ topic-and-industry/extractives/guidance-position-statements/health-and-safety-at-opencast-mines-alluvial-minesand-quarries/

13. Bitimbaev, M.Zh., Kuzmin, S.L., Maulyanbaev, T. I., Osadchy, V. I., \& Oryngozhin, E. S. (2015). The use of container technology for open pit mining. Monograph. Almaty: Aleshan. 
14. Bitimbaev, M. Zh., Kuzmin, S. L., \& Tyurbit, A. N. (2018). Equipment for the transportation of rocks during mining operations. Patent No. 33091, Kazakhstan.

\section{Енергетичні переваги контейнерної транспортної технології у глибоких кар'єрах}

\section{О. Сладковськи ${ }^{1}$, А. Утегенова ${ }^{2}$, С. Кузьмін ${ }^{3}$, Б. Ракішев ${ }^{2}$, I. Столповських ${ }^{2}$}

1 - Сілезький технічний університет, м. Катовіце, Польща, e-mail: aleksander.sladkowski@polsl.pl

2 - Університет Сатбаєва, м. Алмати, Республіка Казахстан, e-mail: asem_u_18@mail.ru

3 - Рудненський індустріальний інститут, м. Рудний, Республіка Казахстан, decan_2008@mail.ru

Мета. Обгрунтування раціональних параметрів нової контейнерної технології переміщення гірських порід у кар'єрах, що має технологічні та енергозберігаючі переваги.

Методика. У роботі використаний комплекс наукових методів досліджень: наукове узагальнення та технікоекономічний аналіз досвіду експлуатації транспортних систем; енергетичний аналіз процесів відкритих гірничих робіт; економіко-математичний аналіз; багатофакторний аналіз.

Результати. У результаті виконаних проектно-конструкторських і техніко-економічних розрахунків обгрунтовані раціональні параметри нової контейнерної технології переміщення гірської маси в кар'єрах.

Наукова новизна. Уперше виконано комплексний аналіз роботи транспортних систем у кар'єрах на основі аналізу структури й динаміки енергоспоживання на глибоких кар'єрах. Встановлено, що витрата енергії на технологічні перевезення у глибоких кар'єрах складає від 22-55 \% при складальних перевезеннях і до 85-90 \% при магістральних автоперевезеннях у загальних енерговитратах на видобуток гірської маси. Для підвищення енергетичної ефективності транспортних систем кар'єрів обгрунтовані раціональні конструктивні й режимні параметри нової контейнерної технології у глибоких кар'єрах, що дозволяє змінити принципи формування екскаваторів і транспортних комплексів, підвищить їх продуктивність і енергоефективність. Розроблена методика розрахунку техніко-економічних і енергетичних показників контейнерної технології транспортування гірничої маси, заснована на геоінформаційному моделюванні фронту гірничих робіт i виробничій потужності глибоких кар'єрів.

Практична значимість. На основі встановлених раціональних параметрів нової контейнерної технології на стадії проектування можна приймати обгрунтовані технічні рішення, що забезпечують енергетично ефективну роботу транспортних систем глибоких кар>єрів.

Ключові слова: контейнерна технологія, глибокий кар'єр, підйомна машина, продуктивність, відкриті гірничі роботи, екскаваторно-транспортний комплекс

\section{Энергетические преимущества контейнерной транспортной технологии в глубоких карьерах}

\author{
А. Сладковски ${ }^{1}$, А. Утегенова ${ }^{2}$, С. Кузьмин ${ }^{3}$, \\ Б. Ракишев ${ }^{2}$, И. Столповских ${ }^{2}$
}

1 - Силезский технический университет, г. Катовице, Польша, e-mail:aleksander.sladkowski@polsl.pl

2 - Университет Сатпаева, г. Алматы, Республика Казахстан, e-mail: asem_u_18@mail.ru

3 - Рудненский индустриальный институт, г. Рудный, Республика Казахстан, decan_2008@mail.ru

Цель. Обоснование рациональных параметров новой контейнерной технологии перемещения горных пород в карьерах, обладающей технологическими и энергосберегающими преимуществами.

Методика. В работе использован комплекс научных методов исследований: научное обобщение и техникоэкономический анализ опыта эксплуатации транспортных систем; энергетический анализ процессов открытых горных работ; экономико-математический и многофакторный анализ.

Результаты. В результате выполненных проектноконструкторских и технико-экономических расчетов обоснованы рациональные параметры новой контейнерной технологии перемещения горной массы в карьерах.

Научная новизна. Впервые выполнен комплексный анализ работы транспортных систем в карьерах на основе анализа структуры и динамики энергопотребления на глубоких карьерах. Установлено, что расход энергии на технологические перевозки в глубоких карьерах составляет от 22-55 \% при сборочных перевозках и до 85-90\% при магистральных автоперевозках в общих энергозатратах на добычу горной массы. Для повышения энергетической эффективности транспортных систем карьеров обоснованы рациональные конструктивные и режимные параметры новой контейнерной технологии в глубоких карьерах, которая позволяет изменить принципы формирования экскаваторов и транспортных комплексов, повысить их производительность и энергоэффективность. Разработана методика расчета технико-экономических и энергетических показателей контейнерной технологии транспортирования горной массы, основанная на геоинформационном моделировании фронта горных работ и производственной мощности глубоких карьеров.

Практическая значимость. На основе установленных рациональных параметров новой контейнерной технологии, на стадии проектирования можно принимать обоснованные технические решения, обеспечивающие энергетически эффективную работу транспортных систем глубоких карьеров.

Ключевые слова: контейнерная технология, глубокий карьер, подбемная машина, контейнер, производительность, открытые горные работы, экскаваторно-транспортный комплекс

Рекомендовано до публікації докт. техн. наук Х. А. Юсуповим. Дата надходження рукопису 12.01.19. 